\title{
KILKA UWAG W SPRAWIE RZEKOMEGO WYWIEZIENIA CZĘŚCI ZBIORÓW BIBLIOTEKI CYSTERÓW W SZCZYRZYCU DO LWOWA,TARNOWA CZY INNYCH BIBLIOTEK
}

Klasztor szczyrzycki, choć niewielki doczekał się w ostatnich latach wielu cennych opracowań, głównie za sprawą znakomitej znawczyni problematyki cysterskiej p. dr hab. Jolanty M. Marszalskiej. Ważna część tych opracowań poświęcona była klasztornemu księgozbiorowi historycznemu. Warto wymienić tu choćby Katalog inkunabułów ${ }^{l}$, a przede wszystkim najnowsze, monograficzne opracowanie poświęcone księgozbiorowi i jego dziejom do końca XIX w. ${ }^{2}$ Za sprawą wyżej wspomnianej badaczki we współpracy z prof. Ewą Łużyniecka i ks. prof. Waldemarem Graczykiem powstały dwa opracowania: pierwsze poświęcone dziejom budowy opactwa szczyrzyckiego ${ }^{3}$, drugie zaś opatom klasztoru, począwszy od pierwszego w XIII w. - Tecelina a skończywszy na ostatnim (obecnym) - Eugeniuszu ${ }^{4}$. Dzięki tej wytrwałej pracy badawczej, prowadzonej ze szczególnym natężeniem w ostatnich latach, nasza wiedza na temat klasztoru szczyrzyckiego znacznie się poszerzyła. Może więc nieco dziwić, że mimo tego, iż nasza wiedza na temat Szczyrzyca w chwili obecnej jest znacznie większa niż np. 10 lat temu i często weryfikuje ona wcześniejsze przekazy, to mimo to nie brakuje badaczy, którzy prawie automatycznie powielają dawne ustalenia.

By osadzić zasadniczą tezę referatu na fundamencie historycznym, pragnę zaznaczyć, że klasztor cystersów w Szczyrzycu, nieprzerwanie prowadzi swoją działalność, wynikającą z charyzmatu, od XIII w. aż do chwili obecnej, z tym

* Ks. Waldemar Graczyk - dr hab. historii, prof. UKSW w Warszawie.

${ }^{1}$ J. M. Marszalska, Katalog inkunabułów biblioteki opactwa oo. Cystersów w Szczyrzycu, Tyniec 2002.

${ }^{2}$ J. M. Marszalska, Biblioteka opactwa Cystersów w Szczyrzycu do końca XIX stulecia. Dziedzictwo wieków, Tarnów 2007.

${ }^{3}$ E. Łużyniecka, J. M. Marszalska, Szczyrzyc. Dzieje budowy opactwa cysterskiego, Wrocław 2005.

${ }^{4}$ J. M. Marszalska, W. Graczyk, Opaci i przeorzy klasztoru oo. Cystersów w Szczyrzycu od XIII do XX wieku, Tyniec 2006. 
wszakże zastrzeżeniem, że po śmierci w 1794 r. opata Józefa Onufrego Grzymisławskiego, władze zaborcze austriackie nie zezwoliły na wybór nowego opata i oddały klasztor pod jurysdykcję opata jędrzejowskiego. Tym samym opactwo szczyrzyckie zostało zredukowane do rangi przeoratu, ale nie znaczy to wcale, że przestało istnieć a dobra jego uległy rozproszeniu jak było w przypadku wielu skasowanych opactw cysterskich na ziemiach polskich. Taka sytuacja przetrwała aż do 1918 r., kiedy to papież Benedykt XV na prośbę przeora Teodora Magiery, przywrócił klasztorowi status opactwa 5 .

Co zainspirowało mnie do przedstawienia tych kilku uwag na temat rzekomego wywiezienia części zbiorów biblioteki klasztoru szczyrzyckiego do Lwowa? Otóż jesienią 2007 r. otrzymałem wydawnictwo zbiorowe pt. Ingenio et humilitate. Studia z dziejów zakonu cystersów i Kościoła na ziemiach polskich, pod red. Andrzeja Wyrwy ${ }^{6}$. Zainteresował mnie w tym wydawnictwie artykuł autorstwa pań, Jolanty Gwioździk i Iwony Pietrzkiewicz pt. Stróż serdeczny albo rozmyślania nabożne. Lwowski ślad biblioteki cystersów szczyrzyckich. Autorki powołując się na wcześniejsze wzmianki na temat księgozbioru szczyrzyckiego autorstwa np. Józefa Łepkowskiego i Józefa Jerzmanowskiego ${ }^{7}$, Cezarego Biernackiego ${ }^{8}$, Franciszka Radziszewskiego ${ }^{9}$ czy Gerarda Kowalskiego ${ }^{10}$, odnotowały: ,[...] wywiezienie pewnej części zbiorów [szczyrzyckich] do Lwowa nie powinno budzić watpliwości [...] dlatego też w połowie XIX wieku w klasztorze pozostało zaledwie 1101 dzieł"11. Właśnie zapis ten jak i fakt wywiezienia części lub całości zbiorów szczyrzyckich budzi moje wątpliwości, stąd też kilka słów refleksji na ten temat.

Pierwsza informacja na temat rzekomego wywiezienia znacznej części księgozbioru szczyrzyckiego do Lwowa i Tarnowa jest stosunkowo późna i pochodzi dopiero z 1850 r. Została zamieszczona w Bibliotece Warszawskiej, tomie 3, na stronie 215. Była ona owocem podróży archeologicznej po Galicji, odbytej przez Józefa Łepkowskiego i Józefa Jerzmanowskiego w 1849 r. Autorzy tej relacji odnośnie do biblioteki szczyrzyckiej zanotowali ,[...] ze śmiercią ostatniego opata w r. 1794 wywieziono znaczną część książek do Lwowa, i wcielono wraz z innymi po zniesionych w całym kraju klasztorach do biblioteki uniwersyteckiej, którą

${ }^{5}$ Tamże, s. 10, 219.

${ }^{6}$ Ingenio et humilitate. Studia z dziejów zakonu cystersów i Kościoła na ziemiach polskich, red. A. Wyrwa, Poznań 2007.

${ }^{7}$ J. Łepkowski, J. Jerzmanowski, Utamek z podróży archeologicznej po Galicji, odbytej w roku 1849, „Biblioteka Warszawska”, 3 (1850) s. 193-224.

${ }^{8}$ C. Biernacki, Szczyrzyce lub Szczyrzyc, w: Encyklopedia Powszechna, t. 24, Warszawa 1867, s. $596-597$.

${ }^{9}$ F. Radziszewski, Wiadomość historyczno-statystyczna o znakomitych bibliotekach polskich, Kraków 1875, s. 81-82.

${ }^{10}$ G. Kowalski, Katalog inkunabułów biblioteki opactwa mogilskiego oraz katalog inkunabutów biblioteki klasztoru cystersów w Szczyrzycu, Kraków, 1915, s. IX.

${ }^{11}$ J. Gwioździk, I. Pietrzkiewicz, „Stróż serdeczny albo rozmyślania nabożne”. Lwowski ślad biblioteki cystersów szczyrzyckich, w: Ingenio et humilitate. Studia z dziejów zakonu cystersów i Kościoła na ziemiach polskich, red. A. Wyrwa, Poznań 2007, s. 242. 
d. 2 listopada 1848 r. spalono. Część także przewieziono do dyecezalnego seminaryum, będącego dziś w Tarnowie. Obecnie bibliotekę w Szczyrzycu obejmuje jedna mała cela o jednym oknie, w której się mieści zaledwie 1101 dzieł"12. Wiarygodności tej informacji nikt później już nie weryfikował a co więcej wielu badaczy tak XIX i XX wiecznych jak i współczesnych, bezkrytycznie ją powielało. Dość, że wymienię tu Cezarego Biernackiego, który w haśle Szczyrzyc, opublikowanym w 24 tomie Encyklopedii Powszechnej w 1867 r. odnotował: „,...] ze śmiercią ostatniego opata, znaczną część książek wywieziono do Lwowa, i wcielono wraz z innemi po zniesionych w całym kraju klasztorach do biblioteki uniwersyteckiej, która dnia 2 listopada 1848 r. spalono. Część także przewieziono do dyjecezalnego seminaryjum, będącego dziś w Tarnowie. Obecnie bibliotekę w Szczyrzycu obejmuje, jedna mała cela, w której mieści się zaledwie 1101 dzieł"13. Prawie 20 lat później to samo napisał Franciszek Radziszewski, który w opublikowanych w 1875 r. Wiadomościach historyczno-statystycznych o znakomitych bibliotekach polskich, odnośnie do Szczyrzyca zamieścił „Biblioteka klasztorna xx Cystersów, jedna z najdawniejszych i dosyć liczna; w r. 1794 część jej wywieziono do Lwowa i wcielono do biblioteki uniwersyteckiej, a część oddano do Tarnowskiego seminarium. Pozostała na miejscu biblioteka zawierała jeszcze do 1100 dzieł [...]"14. Zatem jest to prawie in extenso powielenie informacji Józefa Łepkowskiego i Józefa Jerzmanowskiego, jedynie może z zaokrągleniem liczby woluminów znajdujących się w bibliotece.

Już w XX w. powtórzył ten zapis Gerard Kowalski, który w książce pt. Katalog inkunabutów biblioteki opactwa mogilskiego oraz katalog inkunabutów biblioteki klasztoru cystersów w Szczyrzycu, wydanej w 1915 r. odnośnie do biblioteki szczyrzyckiej odnotował: ,[...] biblioteka bardzo ucierpiała, gdyż w r. 1794 rękopisy i znaczną część druków wywieziono do Lwowa i wcielono wraz z innemi po zniesionych w całym karju klasztorach do biblioteki uniwersyteckiej, gdzie podczas pożaru w r. 1848 spłonęły. Część biblioteki przewieziono do tarnowskiego seminaryum duchownego" ${ }^{15}$. Zatem praktycznie, począwszy od $1850 \mathrm{r}$. na temat biblioteki szczyrzyckiej były przekazywane te same, niesprawdzone informacje. Ten właściwie ,jednogłos” w sprawie Szczyrzyca został nieco zachwiany wypowiedzią Edwarda Chwalewika, który w dziele Zbiory polskie, w tomie 2, opublikowanym w 1927 r. pod hasłem Szczyrzyc odnotował: „Archiwum i biblioteka oo. Cystersów liczy ok. 1500 dzieł [...]. W w. XIX wiele książek wywieziono stąd do Petersburga, Warszawy, Tarnowa i Lwowa"16.

Jak już wspomniano najnowszą wypowiedzią na temat losów biblioteki szczyrzyckiej jest wzmiankowany artykuł Jolanty Gwioździk i Iwony Pietrzkiewicz. Autorki, właściwie jako kolejne powieliły przekaz Józefa Łepkowskiego i Józefa

${ }^{12}$ Łepkowski, Jerzmanowski, Utamek z podróży archeologicznej po Galicji, s. 215.

${ }^{13}$ Biernacki, Szczyrzyce, s. 597.

${ }^{14}$ F. Radziszewski, Wiadomość historyczno-statystyczna o znakomitych bibliotekach polskich, Kraków 1875, s. 81.

${ }^{15}$ Kowalski, Katalog inkunabułów, s. IX.

${ }^{16}$ E. Chwalewik, Zbiory polskie. Archiwa, biblioteki, gabinety, galerie, muzea i inne zbiory pamiatek przeszłości w ojczyźnie i na obczyźnie, t. 2, Warszaw 1927, s. 228-229. 
Jerzmanowskiego, wzmacniając go jeszcze informacją Edwarda Chwalewika o wywiezieniu książek ze Szczyrzyca, oprócz Lwowa i Tarnowa do Warszawy i Petersburga ale już przemilczały podawaną przez niego ok. 1500 liczbę woluminów biblioteki szczyrzyckiej, która była przecież znacznie wyższą od podawanej 1101.

Pragnę zatem w tym miejscu postawić kilka pytań odnoszących się do biblioteki cystersów w Szczyrzycu i postaram się udzilić na nie odpowiedzi. Czy zatem z faktu likwidacji opactwa po śmierci w 1794 r. opata Józefa Onufrego Grzymisławskiego, można wyprowadzać wniosek o wywiezieniu księgozbioru? Otóż nie, bowiem likwidacja opactwa, pociagała za sobą jedynie zmianę statusu klasztoru, a nie była de facto jego likwidacją. Klasztor wówczas poniósł pewne straty materialne np. część dóbr opactwa zajęto na rzecz skarbu państwa i publicznie zlicytowano np. spichlerz opacki, sprzedano hrabiemu Marcelemu Dzieduszyckiemu co też zostało skrupulatnie odnotowane ${ }^{17}$. Straty jakie poniósł wówczas klasztor w Szczyrzycu zostały zestawione przez Władysława Chotkowskiego, łącznie z informacją, kiedy i za jaką kwotę, klasztor odkupił daną posiadłość ${ }^{18}$. Gdyby zatem księgozbiór klasztorny został wywieziony to taki fakt bez wątpienia zostałby odnotowany w dokumentach klasztornych.

Skąd pojawił się Lwów i biblioteka uniwersytecka jako miejsce przewiezienia zbiorów szczyrzyckich? Prawdopodobnie stąd, że zbiory skasowanych klasztorów z terenu zaboru austriackiego istotnie trafiały do Biblioteki Uniwersytetu we Lwowie. W opracowanej przez Ludwika Finkla i Stanisława Starzyńskiego w 1894 r. Historii Uniwersytetu lwowskiego został zamieszczony szczegółowy wykaz wszystkich skasowanych klasztorów, których zbiory zostały włączone do biblioteki uniwersyteckiej. Znalazły się więc we Lwowie zbiory ze skasowanych klasztorów: augustianów, bazylianów, benedyktynów, benedyktynek, bernardynów, dominikanów, franciszkanów, kapucynów, karmelitów, paulinów, pijarów czy reformatów ${ }^{19}$. Nie ma w tym dziele żadnej wzmianki o przewiezieniu choćby części zbiorów cystersów szczyrzyckich do Lwowa. Zatem Józef Łepkowski i Józef Jerzmanowski a za nimi wszyscy wyżej wzmiankowani, pisząc o wywiezieniu księgozbioru szczyrzyckiego do Lwowa, oparli się na prostym schemacie myślowym - skoro księgozbiory wszystkich skasowanych klasztorów zostały wywie-

${ }^{17}$ Arch. i BOCist. sygn. IV. 62; Marszalska, Graczyk, Opaci i przeorzy, s. 184.

18, ,[...] po 7 latach (1794) zabrano dobra opackie i sprzedano: 1) klucz szczyrzycki z Krzyszkowicami za 15.242 fl. (R. 1855 odkupił go konwent za 70.000 fl). 2) Klucz Abramowice, Pogorzany, Śmigań [Smykań], Góra św. Jana, Porembczyn [Pobręczyn] i Wilkowiska, dano hr. Dzieduszyckiemu w zamian za dobra solankowe. Wartość oznaczono 23.417 fl. 3) Klucz Ludźmierz z Krauszowem i Rogoźnikiem sprzedano (1819 za 14.095 fl. Fundusz religijny zyskał więc ze sprzedaży tych dóbr razem 52.726 fl. Konwent w Szczyrzycach cystersów utrzymał się dotą chociaz mu groziło kilkakrotne zniesienie. Pozostawino mu dominium Janowice t.j. 8 wsi: Janowice, Raciborzany, Dobroniów, Gruszów, Markoszowe, Godziska i Porębka [Porąbka]" (W. Chotkowski, Grabieże kościelne w Galicji, cz. 1, Kraków 1919, s. 48).

${ }^{19}$ L. Finkel, S. Starzyński, Historia Uniwersytetu Lwowskiego, Lwów 1894, przyp. nr 3, s. 121 -122 . 
zione do Lwowa, to również i zbiory lub ich część skasowanego opactwa w Szczyrzycu.

Jeszcze bardziej pozbawiona podstaw wydaje się informacja o przewiezieniu po śmierci w 1794 r. ostatniego opata szczyrzyckiego, Józefa Onufrego Grzymisławskiego - zbiorów szczyrzyckich do seminarium duchownego w Tarnowie. Przecież diecezja tarnowska nie posiadała w tym czasie własnego seminarium duchownego. Choćby w relacji do Rzymu z 1 IX 1800 r. biskup Florian Amand Janowski, nie omieszkał zaznaczyć, ze diecezja nadal nie posiada własnego seminarium. Możliwość utworzenia seminarium w Tarnowie pojawiła się dopierow 1821 r. kiedy to papież Pius VII w bulli Studium paterni affectus zalecił przyszłemu ordynariuszowi tynieckiemu zorganizowanie seminarium duchownego. Po upływie pięciu lat od wydania bulli w relacji do Rzymu z 5 XII 1826 r. biskup Tomasz Grzegorz Ziegler zaznaczył, że seminarium duchowne, dzięki wspaniałomyślnej szczodrobliwości cesarza Franciszka I jest w budowie od fundamentów ${ }^{20}$. Zatem w 1850 r. kiedy Józef Łepkowski i Józef Jerzmanowski publikowali w Bibliotece Warszawskiej, swoje informacje na temat przewiezienia zbiorów szczyrzyckich do seminarium tarnowskiego, seminarium wówczas już istniało, ale nie było go bez wattpienia w 1794 r. Czyli ich informacja jest pozbawiona jakichkolwiek podstaw merytorycznych.

Informacja na temat wywiezienia części zbiorów szczyrzyckich do Petersburga również jest nie do utrzymania, albowiem badania podjęte przez Józefa Korzeniowskiego na przełomie XIX i XX w., które zostały następnie ogłoszone drukiem w Krakowie w 1910 r. w wydawnictwie pt. Zapiski z rękopisów Cesarskiej Biblioteki Publicznej w Petersburgu i innych Bibliotek petersburskich. Sprawozdania z podróży naukowych odbytych w latach 1891-1892 i w 190721, wykazały obecność w Petersburgu fragmentów księgozbiorów następujących zakonów i klasztorów: benedyktynów, bernardynów, bożogrobców, cystersów z Koprzywnicy, cystersów z Lądu, cystersów z Wąchocka, cystersów z Sulejowa, jezuitów, kamedułów, misjonarzy, paulinów, premonstratensów czy dominikanów. Obecności jakiegoś fragmentu księgozbioru cystersów ze Szczyrzyca w Petersburgu, Józef Korzeniowski nie odnotował.

W różnych katalogach rękopisów czy starych druków pojawiają się wzmianki na temat obecności jakiegoś dzieła z notą proweniencyjną klasztoru szczyrzyckiego. Dla przykładu Katalog starych druków Biblioteki Zakładu narodowego im. Ossolińskich. Polonica wieku XVI, wydany w Warszawie w 1965 r. pod numerami 443b i 917d wymienia dzieła z wyraźnym zapisem własnościowym „Ex libris conventus Ciricensis", czy Katalog druków XV i XVI wieku w zbiorach Biblioteki Uniwersyteckiej $w$ Warszawie w t. 1, cz. 2, wydanej w Warszawie w 1994 r. pod numerem 112 wymienia XVI - wieczny starodruk z proweniencją szczyrzycka.

${ }^{20}$ B. Kumor, Diecezja tarnowska. Dzieje ustroju i organizacji 1786-1985, Kraków 1985, s. 482-486 .

${ }^{21}$ J. Korzeniowski, Zapiski z rękopisów Cesarskiej Biblioteki Publicznej w Petersburgu i innych Bibliotek petersburskich. Sprawozdania z podróży naukowych odbytych w latach 1891-1892 i w 1907, w: Archiwum do dziejów literatury i oświaty w Polsce, t. 11, Kraków 1910. 
I wreszcie wiele danych na temat księgozbioru klasztornego i jego losów może dostarczyć nam sam zasób książek i jego inwentarze - zwłaszcza te, pochodzace z XIX w. Do chwili obecnej zachowały się w Archiwum oo. Cystersów w Szczyrzycu dwa XIX - wieczne Inwentarze z 1826 i 1869 r. Zostały one szczegółowo omówione przez Jolantę M. Marszalską w publikacji: Biblioteka opactwa Cystersów w Szczyrzycu do końca XIX stulecia. Dziedzictwo wieków, wydanej w Tarnowie w 2007 r. Pierwszy z wymienionych inwentarzy - z 1826 r. zawiera łącznie 1508 tytułów dzieł, pogrupowanych w 21 tematycznych działów ${ }^{22}$. Analogicznie i w drugim inwentarzu z 1869 r. cały zasób biblioteki klasztornej został podzielony na działy, takie same jak w inwentarzu z 1826 r. Spisujący księgi odnotował obecność w bibliotece klasztornej 1465 tytułów dzieł ${ }^{23}$. Zatem różnica w zasobie księgozbioru jest raczej niewielka. Różnica czasowa 43 lat od spisania inwentarzy pokazuje, że księgozbiór nie rozwijał się, ale też i w jakiś dramatyczny sposób nie uległ zmniejszeniu. Skąd zatem ta liczba ksiag 1101 podana przez Józefa Łepkowskiego i Józefa Jerzmanowskiego a za nimi przez innych badaczy - trudno stwierdzić, tym bardziej, że po 1794 r. klasztor nastawiony był bardziej na przetrwanie i nie obserwuje się jakiegoś intensywnego rozwoju w tym również intelektualnego. A bez wattpienia z takowym musielibyśmy mieć do czynienia zakładając, że w latach 1794-1826 zasób biblioteki zwiększył się o 407 tytułów. W każdym razie w Archiwum klasztornym nie znajdują się żadne informacje pozwalające wyjaśnić - przyjmując oczywiście dane Józefa Łepkowskiego i Józefa Jerzmanowskiego - ten zadziwiająco wysoki wzrost liczby ksiąg w klasztorze w tak krótkim stosunkowo czasie.

I jeszcze jedna kwestia, związana tym razem z pomieszczeniami w których księgi były przechowywane. Wyżej wymienieni badacze i wszyscy następni, zgodnie podkreślają, że księgi były przechowywane w jednej celi zakonnej. Tymczasem sporządzający inwentarze zarówno z 1826 jak i 1869 r. wprost napisali, że biblioteka znajdowała się $\mathrm{w}$ dwóch niewielkich pomieszczeniach na pierwszym piętrze budynku klasztornego ${ }^{24}$.

Na koniec pozostaje jeszcze jedna sprawa - jeśli księgozbiór szczyrzycki nie został wywieziony do Lwowa czy Tarnowa to skąd np. obecność w zbiorach Biblioteki Uniwersytetu Lwowskiego dzieła z proweniencją szczyrzycką, które wymieniają Jolanta Gwioździk i Iwona Pietrzkiewicz w artykule: Stróż serdeczny albo rozmyślania nabożne. Lwowski ślad biblioteki cystersów szczyrzyckich, pt. Salomon sive pro religione catholica et dignitate sacerdotale, wydanego w Krakowie w 1588 roku. Otóż losy książki bywały i bywają przeróżne. Obecność w jakiś zbiorach jednego, kilku czy kilkunastu tytułów z taką samą proweniencją nie upoważnia jeszcze do formułowania tezy o przewiezieniu całych zbiorów czy jego znacznej części. Rozumiem, że zaznajomienie się ze starszymi publikacjami na temat księgozbioru szczyrzyckiego, autorów wymienionych w tym przedłożeniu łatwo może pozwolić taką tezę wysnuć. Tymczasem pozostaje jeszcze sam

\footnotetext{
${ }^{22}$ Marszalska, Biblioteka opactwa Cystersów, s. 253-310.

${ }^{23}$ Tamże, s. 138-140.

${ }^{24}$ Tamże, s. 143-147.
} 
księgozbiór i naprawdę interesujące informacje zawarte o nim w miejscowym, klasztornym Archiwum szczyrzyckim.

Reasumując. Teza o wywiezieniu księgozbioru klasztoru szczyrzyckiego lub jego znacznej części do Lwowa czy Tarnowa wydaje się nie do utrzymania. Przeczy temu zarówno sam zasób, który nie zawiera śladów tak znacznego zubożenia jak i brak jakichkolwiek potwierdzonych informacji, które pozwalałyby na utrzymanie tej hipotezy.

\section{EINIGE BEMERKUNGEN ZUM ANGEBLICHEN ABTRANSPORT EINES TEILS DER BIBLIOTHEKSBESTÄNDE DER ZISTERZIENSER VON SZCZYRZYC NACH LEMBERG, TARNÓW UND IN ANDERE BIBLIOTHEKEN}

\section{Zusammenfassung}

Das Zisterzensierkloster in Szczyrzyc entstand in der ersten Hälfte des 13. Jahrhunderts infolge einer Stiftung von Teodor Gryfita. In der Zeit der Polnischen Teilungen befand sich das Kloster im österreichischen Teilungsgebiet. Die österreichischen Behörden, die ihre Politik einer kirchlichen Reorganisation in den besetzten Gebieten konsequent durchsetzten, machten kein Geheimnis aus ihren Plänen, das Kloster zu liquidieren. Dank der in Wien intensiv unternommenen Bemühungen und insbesondere aufgrund der vom Kloster geleiteten Schule und Pfarrgemeinde konnte die Auflösung des Klosters letztendlich doch noch verhindert werden. Es existiert somit ununterbrochen bis auf den heutigen Tag. Wegen der unternommenen Versuche, das Kloster zu liquidieren und seinen Status zu verändern (von der Abtei zum Priorat), sind seit der Mitte des 19. Jahrhunderts bis in die letzten Jahre hinein immer wieder Hypothesen aufgetaucht, ein Teil der wertvollen Bibliotheksbestände sei aus dem Kloster in Szczyrzyc nach Lemberg, Tarnów oder Petersburg abtransportiert worden. Aber nach erfolgter Analyse der erhaltenen Inventarverzeichnisse der Klosterbücher aus dem 19. Jahrhundert und vor allem der Bibliothek selbst muss eine solche Eventualität ausgeschlossen werden. Aufgrund des hier und da erhaltenen Exemplars eines aus dem Kloster in Szczyrzyc stammenden Buches findet die These von der Fortschaffung des gesamten Bestandes der Klosterbibliothek oder eines größeren Teils davon wohl kaum eine Bestätigung. 